\title{
SIMULATION STUDIES TO EVALUATE THE EFFECT OF FRACTURE CLOSURE ON THE PERFORMANCE OF NATURALLY FRACTURED RESERVOIRS
}

\section{Quarterly Report for the Period April-June 1991}

By

Dwight L. Dauben

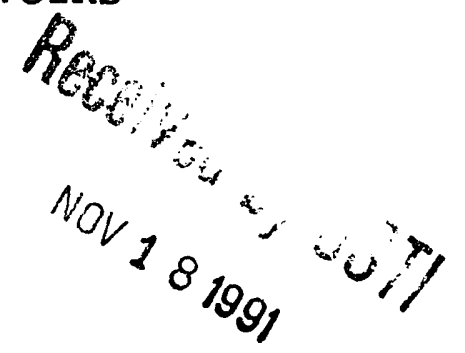

Work Performed Under Contract No. DE-AC22-90BC14654

\author{
Rhonda Patterson, Project Manager \\ Metairie Site Office \\ 900 Commerce Road \\ New Orleans, LA 70123
}

Prepared by

K\&A Energy Consultants

6849 E. 13th Street

Tulsa, OK 74112

\section{DISCLAIMER}

This report was prepared as an account of work sponsored by an agency of the United States Government. Neither the United States Government nor any agency thereof, nor any of their employees, makes any warranty, express or implied, or assumes any legal liability or responsibility for the accuracy, completeness, ur usefulness of any information, apparatus, product, or process disclosed, or represents that its use would not infringe privately owned rights. Reference herein to any specific commercial product, process, or service by trade name, trademark, manufacturer, or otherwise does not necessarily constitute or imply its endorsement, recommendation, or favoring by the United States Government or any agency thereof. The views and opinions of authors expressed herein do not necessarily state or reflect those of the United States Government or any agency thereof. 


\section{IMOLATIOY 8TODIEB TO BVALUATE TRE BFPECT OF FRACTURE CLOBUR: IY THS PERTORYNISE OF NTTURAIT FRACTURED REBERVOIRB}

Progiass Report Number 3 July 15, 1991

\section{OBJECTIVES}

The study has two principal objectives:

1. To evaluate the effects of fracture closure on the recovery of oil and gas reserves from naturally fractured petroleum or natural gas reservoirs.

2. To evaluate procedures for improving the recovery of these reserves using innovative fluid injection techniques to maintain reservoir pressure and mitigate the impact of fracture closure.

The total scope of the study has been subdivided into three main tasks:

1. Baseline studies (non-pressure sensitive fractures) •

2. Studies with Pressure Sensitive Fractures.

3. Innovative Approaches for Improving 011 Recovery.

The tasks to be performed in the current contract year, the Baseline studies task, is comprised of the following sub-tasks:

1a. Development of Representative Reservoir Conditions.

1b. Prediction of Primary Recovery from Vertical Wells.

1c. Prediction of Primary Recovery from Horizontal Wells.

1d. Prediction of Secondary Recovery from Vertical Wells.

1e. Sonsitivity Analyses. 
SUMAARY OF TECHNICAL PROGRESS

An exhaustive search of the technical literature pertaining to thi mechanical and flow behavior of fractured rock systems was carried out. This represented a broadening of the search to include the fields of rock mechanics, hydrology, civil engineering and geophysics as well as petroleum geology and reservoir engineering. The search period was largely limited to 1970 and subsequent years. References to earlier publications were followed up when they appeared to be of interest. Key subjects included:

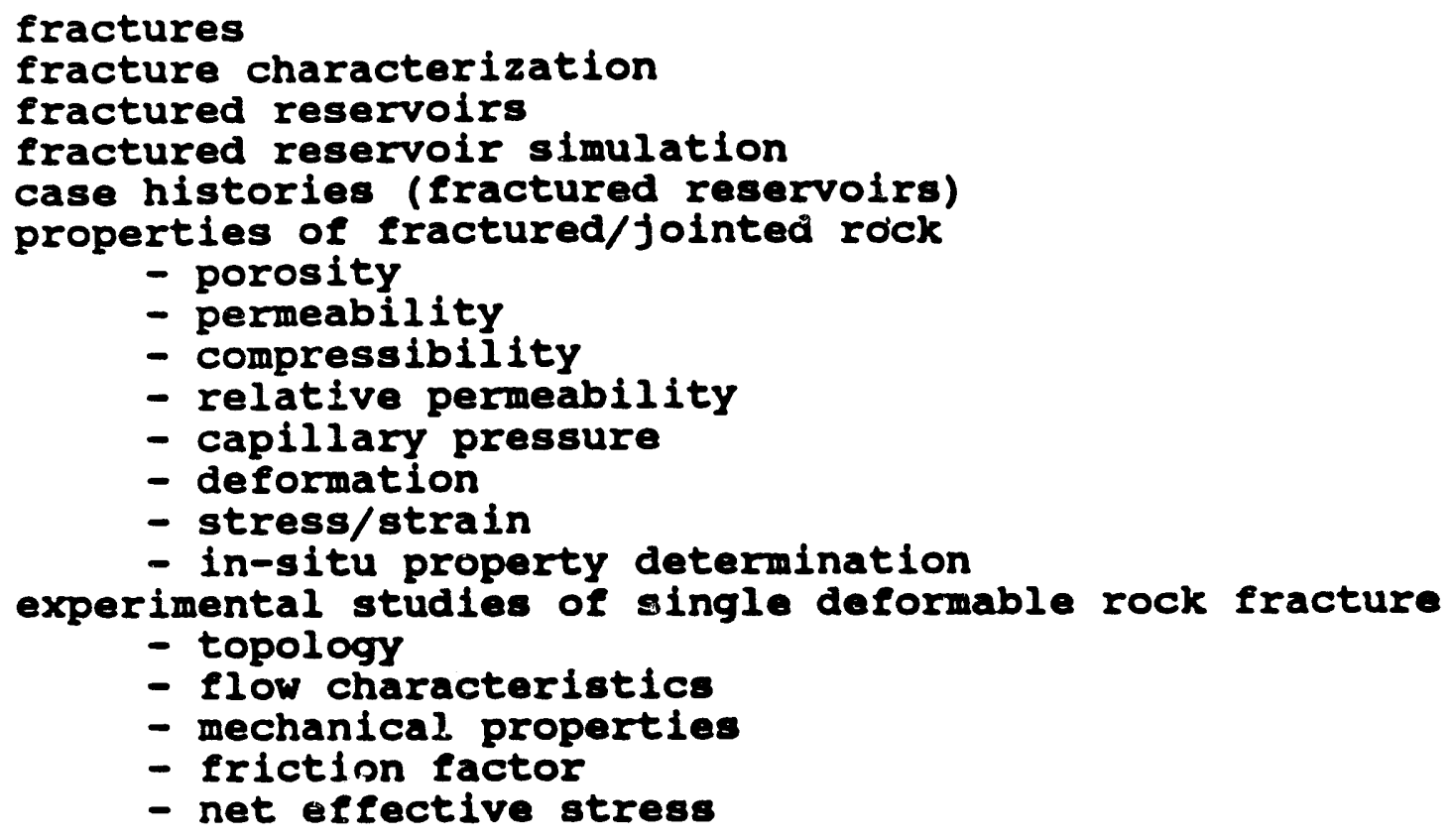

Technical literature indexes were searched for titles suggestive of one or more of the key subjects. Nearly 400 publications were identified as potentially interesting. Abstracts of these were reviewed to elininate roughly one half of the candidates. The remaining 184 publications were copled and added to the 69 identifled by earlier searches of the recent petroleum literature. A more detalled reviow of all 253 publications was approximately 50 complete at the close of the report period.

A data base of all publications is being prepared to assist in the cross referencing and classification of the copied materials. This will also lacilitate bibliography preparation for reporting purposes.

The literature reviow to date has contributed a wealth of information on fractured reservoir behavior erom which it will be possible to select a suitable candidate reservoir for the ongoing study. While no single reservolr has been found with the complete data set needed for simulator initialization, two good candidates 
have been identified in the Austin chalk trend, the Giddings Field and the pearsall field. It is highly likely that one of these reservoirs will be chosen. We are currently reviewing the availibility of data. For each field to determine which has the most comprehensive data set. Assumptions based on experimental studies can be used to fill in the gaps as necessary.

The findings of some of the more interesting experimental data were incorporated in the conceptual model based on the sixth SPE comparison project for dual porosity type simulators. This testing was done to further the validation of the modified program's treatment of permeability in deformable fractures. The deformable fracture aspect of the study is part of the second contract year work scope, nonetheless, the validation of this aspect of the revised program code was considered important enough to be carried out in the current contract year.

A revised milestone schedule, reflecting the current status of the project and the revised plan for the current fiscal year is attached. We have added manpower to the project which we belleve will allow us to complete the current fiscal year tasks during the final quarter. 


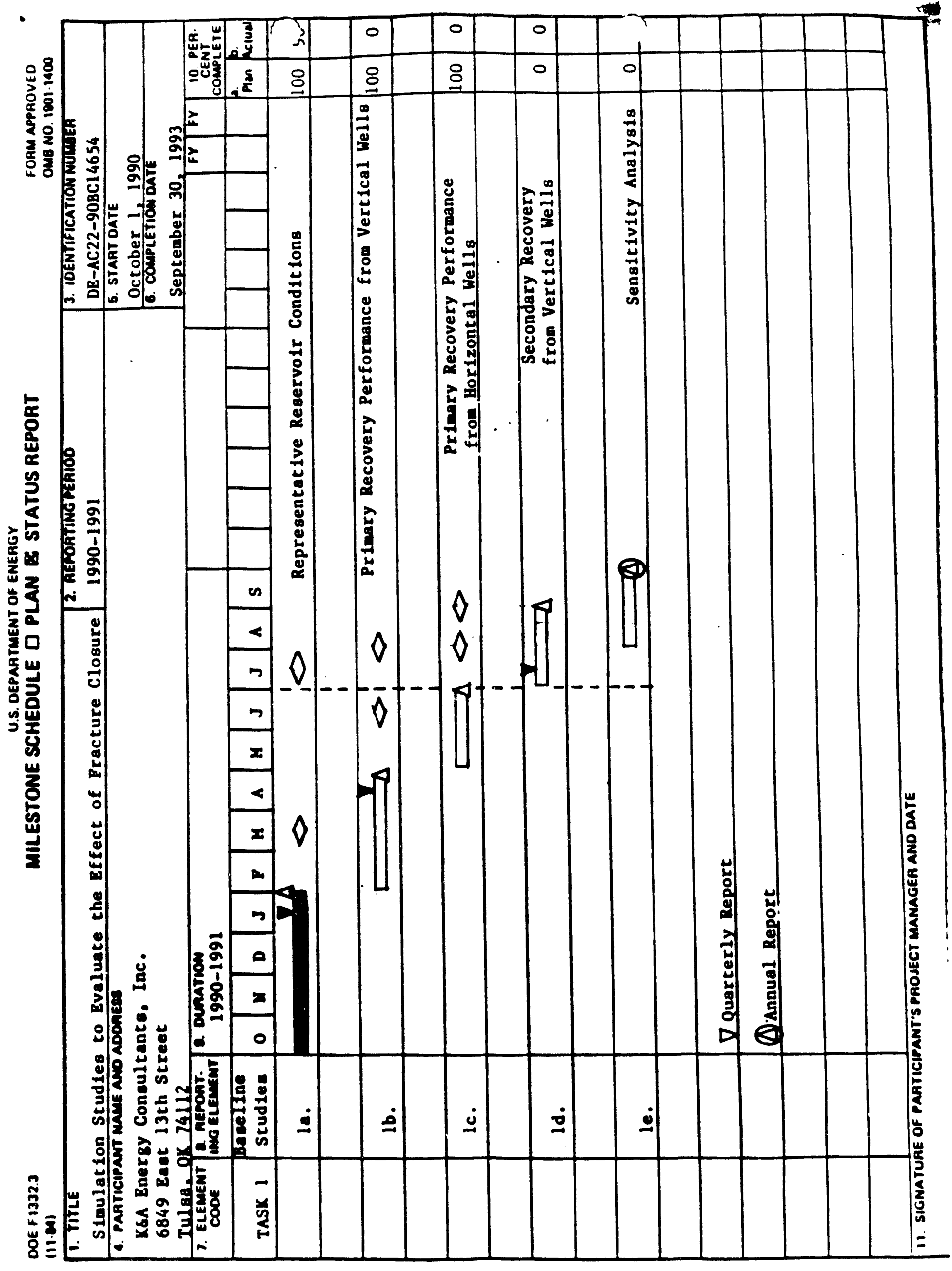



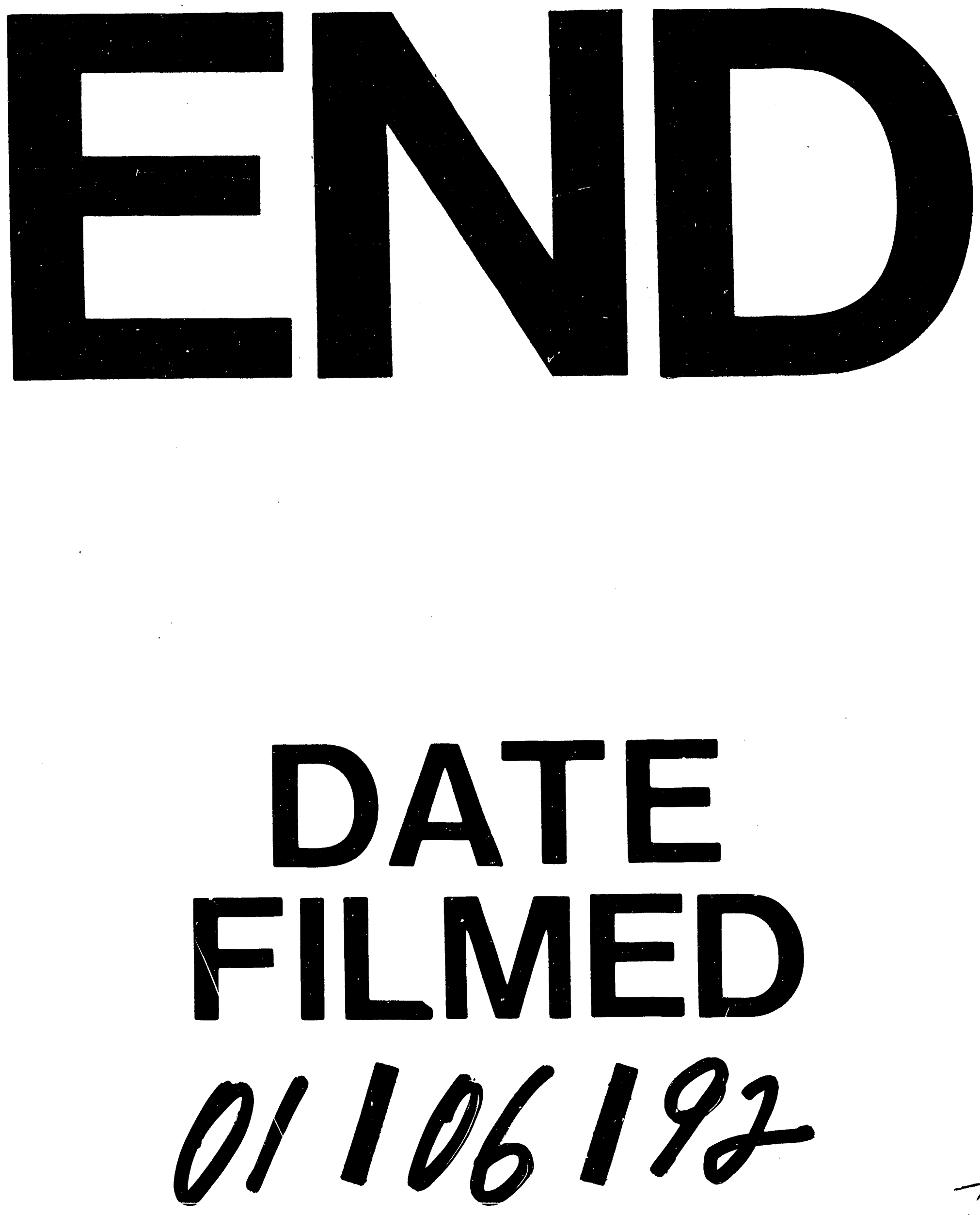
